\section{Dark-stored Flurprimidol Solutions Maintain Efficacy Over Many Weeks}

\author{
William B. Miller ${ }^{1}$ \\ Department of Horticulture, Cornell University, 134 Plant Science Building, \\ Ithaca NY 14853
}

Additional index words. height control, growth regulators, photolysis, spring bulbs, Topflor

\begin{abstract}
For a number of geophytic crops, pre-plant plant growth regulator (PGR) dips or soaks are an effective method of height control. Previous research has shown that a given PGR solution may be used to dip numerous bulbs without losing efficacy. What has been unknown is whether PGR solutions maintain efficacy over multiple-week (seasonal) time scales, especially if they have previously been used to treat bulbs. To address this question, $30 \mathrm{mg} \cdot \mathrm{L}^{-1}$ flurprimidol solutions were prepared 3 weeks apart and used to dip narcissus and hyacinth bulbs and then held for 4 weeks at $17^{\circ} \mathrm{C}$ in darkness. These solutions (now 7 and 4 weeks old) and a freshly prepared solution were used to dip bulbs of eight hyacinth and five narcissus cultivars. After appropriate cooling, bulbs were forced in a greenhouse. Results indicate no difference in growth reduction among the 0-, 4-, or 7-week-old solutions demonstrating no loss of PGR activity over a 7-week period. In two other experiments, $2.5,5$, and $10 \mathrm{mg} \cdot \mathrm{L}^{-1}$ flurprimidol solutions were exposed to 0 to 8 days of full sun (late June) and then used to dip Lilium 'Tresor' bulbs for 1 minute. Growth of the plants indicated loss of growth regulation activity (taller plants) as the duration of exposure to sunlight increased, suggesting substantial photolysis of the active ingredient. Together, the results suggest that flurprimidol solutions can be held in darkness at $17^{\circ} \mathrm{C}$ and used for at least 7 weeks without loss of efficacy.
\end{abstract}

For a number of flower bulb crops, preplant dips or soaks into antigibberellin PGRs are an effective method of height control (Krug et al., 2006a, 2006b; Larson et al., 1987; Ranwala et al., 2005). Previous research has shown that a given solution may be used to dip numerous bulbs without loss of efficacy. For example, at least 55 lily bulbs can be dipped into $1 \mathrm{~L}$ of paclobutazol or uniconazole (Ranwala et al., 2005) and 100 hyacinth bulbs can be dipped into $1 \mathrm{~L}$ of flurprimidol (Krug et al., 2006b) without loss of efficacy as dipping proceeds. A different question is related to the stability of such solutions over time, that is, how long does a PGR solution remain effective when used in a production situation? Data showing stability over multipleweek time scales would reduce the need to make fresh solutions, thereby reducing cost, minimizing disposal issues, and potentially reducing chemical load into the environment. Such information would be very helpful to bulb forcers and other horticultural users of flurprimidol.

The long-term stability of PGR solutions is not generally known, and typical industry practice is to apply spray or drench solutions within several hours of preparation. Dip solutions offer a complication in that the solution

\footnotetext{
Received for publication 17 Oct. 2012. Accepted for publication 19 Nov. 2012.

I am grateful to Anthos (Hillegom, The Netherlands) and SePRO for financial and product support. Special thanks to Simon de Waard, Rose Harmon, and Amanda van den Bosch for excellent technical support during this project.

${ }^{1}$ To whom reprint requests should be addressed; e-mailwbm8@cornell.edu.
}

is usually reused many times and potentially over a long period with accumulation of organic matter (peatmoss, plant debris, etc.). In the case of flurprimidol, previous research (Chand and Lembi, 1994) showed the molecule has a halflife of 8.4 and $9.8 \mathrm{~d}$ in full sun (for initial concentrations of 0.075 and $0.2 \mathrm{mg} \cdot \mathrm{L}^{-1}$, respectively) as an aquatic herbicide in systems consisting of Eurasian watermilfoil, sediment, and water. This result suggests a high likelihood of rapid degradation of the material, especially if exposed to sunlight. Such conditions, however, are quite different from normal floriculture practice in which most bulb dipping activity would be in a headhouse and not in direct sunlight.

The objectives of this experiment were to determine the longevity of flurprimidol solutions when used in a typical commercial fashion and to confirm whether photolysis of flurprimidol occurs in a horticultural situation. Flurprimidol is widely effective as a dip on many bulbous crops (Miller, 2012a, 2013) and for this reason was chosen for this work.

\section{Materials and Methods}

Longevity of previously used dip flurprimidol solutions held in darkness. A flurprimidol solution (14 L, $30 \mathrm{mg} \cdot \mathrm{L}^{-1}$ ) was prepared using the commercial product, Topflor (SePRO, Carmel, IN) and used to dip 144 narcissus and 120 hyacinth bulbs (10 min dips) and then held in darkness at $17{ }^{\circ} \mathrm{C}$. Three weeks later, an identical solution was prepared and used to dip a second group of bulbs and then also held in the dark at $17{ }^{\circ} \mathrm{C}$. After another 4 weeks, a third solution was prepared before the actual start of the experiment. Thus, the experiment consisted of the 7- and 4-week-old "used" flurprimidol solutions and a freshly made (unused) solution. All solutions were held in opaque polyethylene containers.

On 1 Dec., the three solutions and water (non-treated control) were used to dip bulbs of eight hyacinth cultivars and five narcissus cultivars that had previously received 3 weeks of $9{ }^{\circ} \mathrm{C}$ treatment. All bulbs were dipped for $10 \mathrm{~min}$ at $20^{\circ} \mathrm{C}$. After drying at $20^{\circ} \mathrm{C}$ for $2 \mathrm{~h}$, bulbs were planted (one bulb per $10-\mathrm{cm}$ diameter pot) in Lambert LM-111 planting mix (Lambert Peat Moss, Inc., Riviere-Ouelle, Quebec, Canada). Pots were cooled an additional 13 weeks (initially at $9{ }^{\circ} \mathrm{C}$, gradually reducing to $1{ }^{\circ} \mathrm{C}$, for a total cold treatment of 16 weeks) and then forced (starting 2 Mar.) in a glass greenhouse at $17{ }^{\circ} \mathrm{C}$ constant temperature under the natural light conditions prevailing in Ithaca, NY.

Hyacinth cultivars were (bulb diameter in centimeters): 'Blue Jacket' (17/18), 'Carnegie' (18/19), 'Miss Saigon' (18/19), 'Pink Pearl' (18/19), 'Pink Surprise' (17/18), 'Skyline' (17/18), 'Top White' (17/18), and 'Woodstock' (17/18). Narcissus cultivars were 'Carlton' (15/17), 'Exception' (15/17), 'Ice Follies' (15/17), 'Primeur' (15/17), and 'Tete-a-Tete' (12/14).

Measurements of stem height and leaf length (pot rim to tallest point) were made as each plant came into flower and again as the plant was starting to senesce. The difference of these measurements was calculated to determine growth during the flowering period. The experiment had a completely randomized design with 10 and six replicate pots per hyacinth and narcissus cultivar, respectively. JMP Version 9.0.2 (SAS Institute Inc., Cary, NC) was used for data analysis.

Photodegradation of flurprimidol. Two experiments were conducted to determine whether prepared flurprimidol solutions lose activity when exposed to sunlight. Flurprimidol solutions of $\left(2.5,5\right.$, and $\left.10 \mathrm{mg} \cdot \mathrm{L}^{-1}\right)$ were prepared and exposed to full outdoor sun (Ithaca, NY) in late June in 2011 and 2012. Solar radiation $\left(\mathrm{W} \cdot \mathrm{m}^{-2}\right)$ and prevailing air temperature measurements were recorded at 15-min intervals within $100 \mathrm{~m}$ of the research site. In general, the days were mostly sunny with some haze and no significant precipitation. In the first experiment, solutions (initially $6 \mathrm{~L}$ each concentration) were held outdoors in noncovered, translucent white plastic tubs. At the end of each day (sunset), the solution volume was measured and replenished to replace evaporation of water $(\approx 400$ to $\left.500 \mathrm{~mL} \cdot \mathrm{d}^{-1}\right)$. After mixing, a $1-\mathrm{L}$ sample was removed and subsequently held in darkness. This process continued for $6 \mathrm{~d}$.

The second experiment was similar to the first with the exception that the plastic tubs containing the solutions (initially $8 \mathrm{~L}$ ) were tightly sealed with plastic film to eliminate evaporation. One liter of solution was removed each day (for $8 \mathrm{~d}$ ) and subsequently stored in the dark at room temperature. Over the course of the experiment, less than $20 \mathrm{~mL}$ liquid was lost. In both experiments, irradiated solutions were stored in glass bottles until use. 


\begin{tabular}{|c|c|c|c|c|c|c|}
\hline \multirow[b]{2}{*}{ Treatment } & \multicolumn{2}{|c|}{ Length at first flower $(\mathrm{cm})$} & \multicolumn{2}{|c|}{ Length at end of flowering $(\mathrm{cm})$} & \multicolumn{2}{|c|}{ Growth after flowering $(\mathrm{cm})$} \\
\hline & Stem & Leaf & Stem & Leaf & Stem & Leaf \\
\hline Control (no flurprimidol) (C) & 16.4 & 11.9 & 29.8 & 17.3 & 13.4 & 5.4 \\
\hline $30 \mathrm{mg} \cdot \mathrm{L}^{-1}$ flurprimidol, 0 -week-old solution (0) & 13.5 & 8.9 & 22.9 & 11.1 & 9.4 & 2.2 \\
\hline \multicolumn{7}{|l|}{ Contrasts } \\
\hline \multirow[t]{2}{*}{0 vs. 4} & NS & NS & NS & NS & NS & NS \\
\hline & \multicolumn{6}{|c|}{ Carnegie } \\
\hline Control (no flurprimidol) & 18.3 & 12.4 & 26.3 & 16.4 & 8.1 & 4.0 \\
\hline $30 \mathrm{mg} \cdot \mathrm{L}^{-1}$ flurprimidol, 7-week-old solution (7) & 17.2 & 11.9 & 22.6 & 14.7 & 5.4 & 2.8 \\
\hline $30 \mathrm{mg} \cdot \mathrm{L}^{-1}$ flurprimidol, 4-week-old solution (4) & 16.1 & 11.2 & 22.6 & 14.0 & 6.5 & 2.8 \\
\hline $30 \mathrm{mg} \cdot \mathrm{L}^{-1}$ flurprimidol, 0 -week-old solution (0) & 15.5 & 11.0 & 23.0 & 13.7 & 7.6 & 2.7 \\
\hline \multirow[t]{2}{*}{0 vs. 4} & NS & NS & NS & NS & NS & NS \\
\hline & \multicolumn{6}{|c|}{ Miss Saigon } \\
\hline Control (no flurprimidol) & 16.1 & 11.7 & 21.7 & 17.0 & 5.7 & 5.3 \\
\hline $30 \mathrm{mg} \cdot \mathrm{L}^{-1}$ flurprimidol, 7 -week-old solution (7) & 12.9 & 9.2 & 17.7 & 12.6 & 4.8 & 3.4 \\
\hline $30 \mathrm{mg} \cdot \mathrm{L}^{-1}$ flurprimidol, 4-week-old solution (4) & 13.2 & 9.3 & 17.8 & 12.4 & 4.6 & 3.2 \\
\hline $30 \mathrm{mg} \cdot \mathrm{L}^{-1}$ flurprimidol, 0 -week-old solution $(0)$ & 12.5 & 9.0 & 17.3 & 11.8 & 4.8 & 2.8 \\
\hline \multicolumn{7}{|l|}{ Contrasts } \\
\hline C vs. all flurprimidol ages & $* * *$ & $* * *$ & $* * *$ & $* * *$ & * & $* * *$ \\
\hline 0 vs. 7 & NS & NS & NS & NS & NS & NS \\
\hline \multirow[t]{2}{*}{0 vs. 4} & NS & NS & NS & NS & NS & NS \\
\hline & \multicolumn{6}{|c|}{ Pink Pearl } \\
\hline & & & & & & \\
\hline Control (no flurprimidol) & 18.3 & 13.6 & 28.4 & 18.0 & 10.2 & 4.5 \\
\hline $30 \mathrm{mg} \cdot \mathrm{L}^{-1}$ flurprimidol, 7-week-old solution (7) & 13.9 & 10.5 & 21.4 & 13.4 & 7.5 & 2.9 \\
\hline $30 \mathrm{mg} \cdot \mathrm{L}^{-1}$ flurprimidol, 4-week-old solution (4) & 13.5 & 11.5 & 21.7 & 14.8 & 8.2 & 3.3 \\
\hline $30 \mathrm{mg} \cdot \mathrm{L}^{-1}$ flurprimidol, 0 -week-old solution $(0)$ & 13.2 & 11.1 & 20.0 & 14.2 & 6.9 & 3.2 \\
\hline Contrasts & & & & & & \\
\hline C vs. all flurprimidol ages & $* * *$ & $* * *$ & $* * *$ & $* * *$ & $* * *$ & ** \\
\hline 0 vs. 7 & NS & NS & NS & NS & NS & NS \\
\hline 0 vs. 4 & NS & NS & NS & NS & NS & NS \\
\hline & & & & & & \\
\hline Control (no flurprimidol) & 16.6 & 18.0 & 31.2 & 24.8 & 14.6 & 6.9 \\
\hline $30 \mathrm{mg} \cdot \mathrm{L}^{-1}$ flurprimidol, 7-week-old solution (7) & 13.5 & 14.5 & 24.0 & 18.0 & 10.5 & 3.5 \\
\hline $30 \mathrm{mg} \cdot \mathrm{L}^{-1}$ flurprimidol, 4-week-old solution (4) & 13.1 & 14.6 & 23.2 & 18.1 & 10.2 & 3.5 \\
\hline $30 \mathrm{mg} \cdot \mathrm{L}^{-1}$ flurprimidol, 0 -week-old solution (0) & 13.1 & 13.8 & 23.2 & $17.4 \mathrm{~b}$ & 10.2 & 3.6 \\
\hline Contrasts & & & & & & \\
\hline C vs. all flurprimidol ages & $* * *$ & $* * *$ & $* * *$ & $* * *$ & $* * *$ & $* * *$ \\
\hline 0 vs. 7 & NS & NS & NS & NS & NS & NS \\
\hline 0 vs. 4 & NS & NS & NS & NS & NS & NS \\
\hline & & & & & & \\
\hline Control (no flurprimidol) & 22.7 & 18.0 & 28.8 & 20.8 & 6.1 & 2.8 \\
\hline $30 \mathrm{mg} \cdot \mathrm{L}^{-1}$ flurprimidol, 7-week-old solution (7) & 18.6 & 14.2 & 23.7 & 15.8 & 5.2 & 1.6 \\
\hline $30 \mathrm{mg} \cdot \mathrm{L}^{-1}$ flurprimidol, 4-week-old solution (4) & 19.4 & 15.3 & 23.9 & 15.9 & 4.6 & 0.6 \\
\hline $30 \mathrm{mg} \cdot \mathrm{L}^{-1}$ flurprimidol, 0 -week-old solution (0) & 18.7 & 14.8 & 23.3 & 15.6 & 4.6 & 0.8 \\
\hline
\end{tabular}


Table 1. (Continued) Effect of age of flurprimidol dip solutions on growth of eight hyacinth cultivars. ${ }^{\text {. }}$

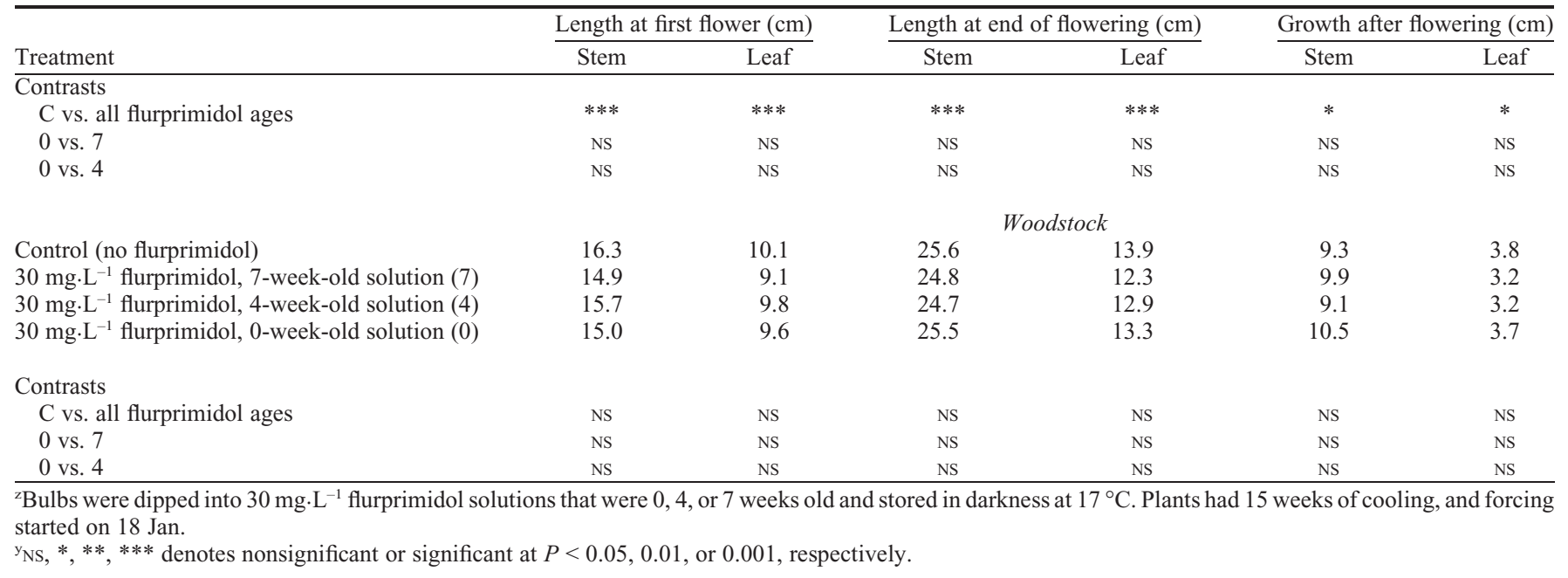

Table 2. Effect of age of flurprimidol dip solutions on growth of five narcissus cultivars. ${ }^{2}$

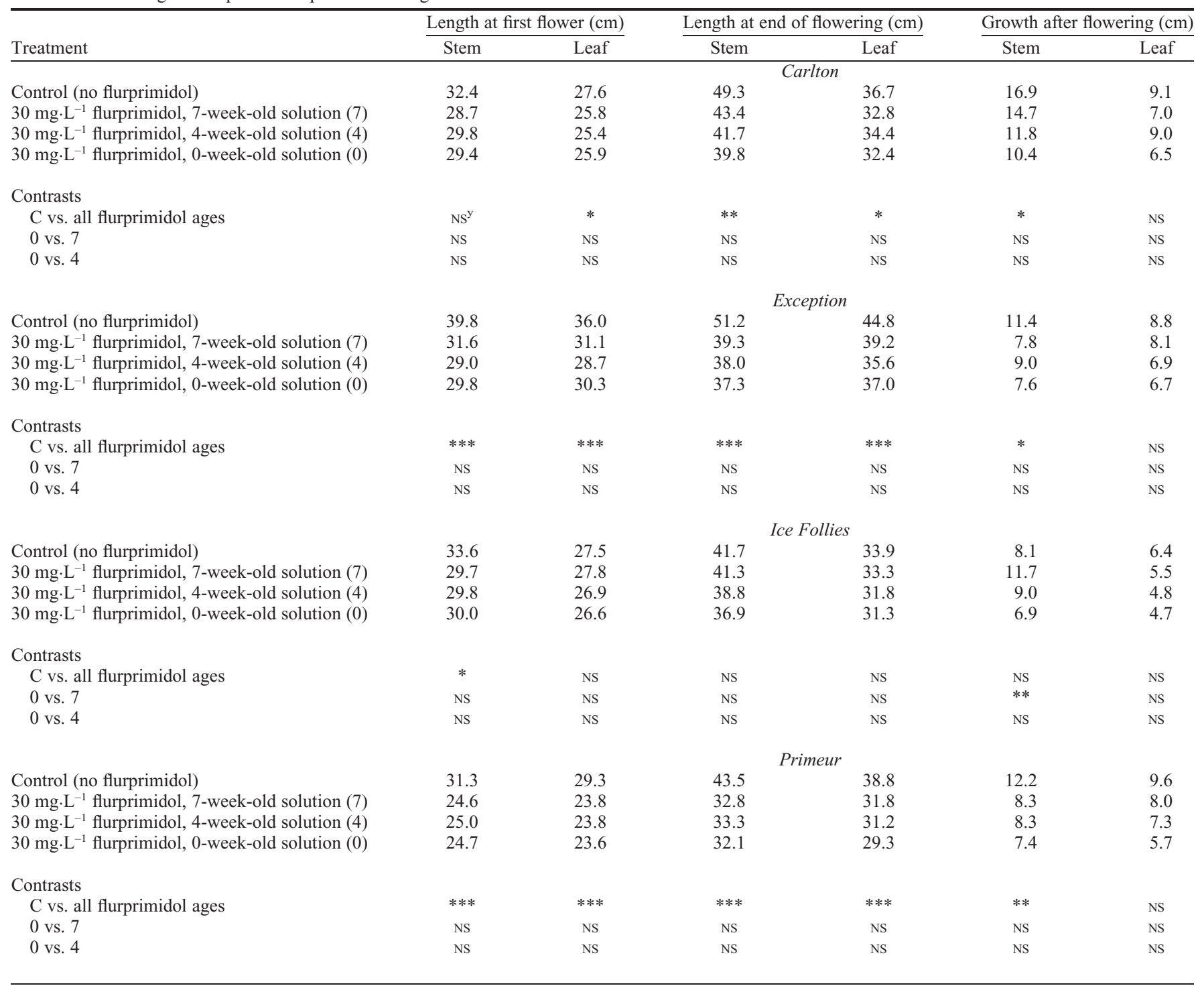


Table 2. (Continued) Effect of age of flurprimidol dip solutions on growth of five narcissus cultivars. ${ }^{\mathrm{z}}$

\begin{tabular}{|c|c|c|c|c|c|c|}
\hline \multirow[b]{2}{*}{ Treatment } & \multicolumn{2}{|c|}{ Length at first flower $(\mathrm{cm})$} & \multicolumn{2}{|c|}{ Length at end of flowering $(\mathrm{cm})$} & \multicolumn{2}{|c|}{ Growth after flowering $(\mathrm{cm})$} \\
\hline & Stem & Leaf & Stem & Leaf & Stem & Leaf \\
\hline & \multicolumn{6}{|c|}{ Tete-a-Tete } \\
\hline Control (no flurprimidol) & 21.3 & 15.9 & 38.5 & 26.3 & 17.2 & 10.4 \\
\hline $30 \mathrm{mg} \cdot \mathrm{L}^{-1}$ flurprimidol, 7-week-old solution (7) & 18.4 & 17.0 & 31.0 & 21.8 & 12.6 & 4.8 \\
\hline $30 \mathrm{mg} \cdot \mathrm{L}^{-1}$ flurprimidol, 4-week-old solution (4) & 18.3 & 15.4 & 30.7 & 21.7 & 12.4 & 6.3 \\
\hline $30 \mathrm{mg} \cdot \mathrm{L}^{-1}$ flurprimidol, 0 -week-old solution (0) & 18.7 & 14.4 & 30.7 & 20.2 & 12.0 & 5.8 \\
\hline \multicolumn{7}{|l|}{ Contrasts } \\
\hline C vs. all flurprimidol ages & $* *$ & NS & $* * *$ & $* * *$ & $* * *$ & $*$ \\
\hline 0 vs. 7 & NS & NS & NS & NS & NS & NS \\
\hline 0 vs. 4 & NS & NS & NS & NS & NS & NS \\
\hline
\end{tabular}

${ }^{\mathrm{z}}$ Bulbs were dipped into $30 \mathrm{mg} \cdot \mathrm{L}^{-1}$ flurprimidol solutions that were 0,4 , or 7 weeks old and held in darkness at $17{ }^{\circ} \mathrm{C}$. Plants had 15 weeks of cooling, and forcing started on 18 Jan.

${ }_{\mathrm{NS}}^{\mathrm{NS}}, * * *, * * *$ denotes nonsignificant or significant at $P<0.05,0.01$, or 0.001 , respectively.

After 6 (Expt. 1) or 8 (Expt. 2) d, the solutions were used to treat (1-min bulb dip) asistic hybrid Lilium 'Tresor' bulbs (12/14 cm circumference). After dipping, bulbs were allowed to dry $\approx 1 \mathrm{~h}$ and then planted into $15-\mathrm{cm}$ diameter plastic pots as described previously. After planting, plants were grown in a glass greenhouse under prevailing light levels at $16^{\circ} \mathrm{C}$ night and $22{ }^{\circ} \mathrm{C}$ day temperature. The experiments were of completely randomized design with eight replicates (bulbs) per treatment. JMP Version 9.0.2 (SAS Institute Inc.) was used for data analysis.

\section{Results and Discussion}

Hyacinth growth. Seven of the eight tested cultivars responded to the flurprimidol dip treatments and generally had shorter flower stems and leaves at the time of first flower and at the end of flowering (Table 1). The cultivar Woodstock was non-responsive. Of the seven responsive cultivars, plants treated with any age flurprimidol solution were significantly shorter than control plants. In six of seven cultivars, there was no significant difference in height of plants dipped into freshly prepared solution as compared with the 4- or 7-weekold solutions (Table 1). The sole exception was 'Carnegie', in which the height of flower stems of plants dipped into the 7-week-old solution was significantly taller than plants dipped into fresh solution. This was the only instance, and considering all other cultivars show a contrary response, is attributed to a sampling or random error. In most cultivars, post-flowering growth (stem or leaf growth from first flower to the end of flowering) was less in the flurprimidol-dipped plants compared with controls, the only exception being with stem growth in 'Carnegie'.

Narcissus growth. Four of the five cultivars were responsive to flurprimidol dips; only 'Ice Follies' was relatively unresponsive at the concentrations used (Table 2). This agrees with previous work showing 'Ice Follies' to be less responsive to flurprimidol dips than other narcissus cultivars (Miller, 2012b). In the cultivars other than 'Ice Follies', stem and leaf length at flowering and end of flowering were generally shorter in flurprimidol-dipped bulbs compared with untreated controls. In all cases, there were no growth differences between fresh solution and 4- or 7-week solution (Table 2).

For both genera, there were no visual effects on flower size, shape, or color.

Flurprimidol photodegradation. The growthretarding activity of flurprimidol solutions was significantly reduced by exposure to sunlight over a period of 1 to $8 \mathrm{~d}$ (Figs. 1 and 2). This effect was seen with each of the irradiated flurprimidol solutions $\left(2.5,5\right.$, and $\left.10 \mathrm{mg} \cdot \mathrm{L}^{-1}\right)$. The environmental conditions during the two experiments are given in Table 3. Temperature and irradiance are expressed as the average of 15-min readings and averaged from sunrise to sunset or summed over this same period (irradiance only). There was no relationship between final plant height as a percent of control and average daily temperature or average daily irradiance. When regressed against accumulated irradiance (MJ), final plant height as a percent of control gave the following equations (Expt. 2): $2.5 \mathrm{mg} \cdot \mathrm{L}^{-1}:-0.0008 \mathrm{x}^{2}+0.2726 \mathrm{x}+76.14\left(r^{2}=\right.$ $0.841 ; \mathrm{F}=0.004) ; 5 \mathrm{mg} \cdot \mathrm{L}^{-1}:-0.0004 \mathrm{x}^{2}+$ $0.2948 \mathrm{x}+62.42\left(r^{2}=0.956 ; \mathrm{F}<0.0001\right) ;$ and $10 \mathrm{mg} \cdot \mathrm{L}^{-1}: 0.0003 \mathrm{x}^{2}+0.2095 \mathrm{x}+51.23\left(r^{2}=\right.$ $0.947 ; \mathrm{F}<0.0001$ ) (data not shown), clearly demonstrating a relationship of accumulated irradiance to degradation of the flurprimidol solution.

Given the different methods used, it is notable that similar results were obtained between the two photodegradation experiments. In Expt. 1 , solutions were uncovered during sunlight exposure, and water evaporated lost each day was replaced before removing and saving the sample. In Expt. 2, solutions were covered with polyethylene film so that evaporation was eliminated. Given the very low vapor pressure of flurprimidol $\left[4.85 \times 10^{-2} \mathrm{mPa}\left(25^{\circ} \mathrm{C}\right)\right.$ vs. $2.3 \mathrm{kPa}$ for water $\left(20^{\circ} \mathrm{C}\right.$ ) (Anonymous, 2012a, 2012 b)] very little, if any, flurprimdol was lost to evaporation in the first experiment as confirmed by the very similar result of the second experiment in which essentially no evaporation occurred.

There are few data in the literature on stability of commercial floriculture PGRs. In the case of flurprimidol, it was shown to have "a half-life of $3 \mathrm{~h}$ in pure water under high light intensities" (Lilly Research Laboratories, 1983, cited in Chand and Lembi, 1994). Flurprimidol had a half-life of 8.4 to $9.8 \mathrm{~d}$ in aquatic systems (Chand and Lembi, 1994) in

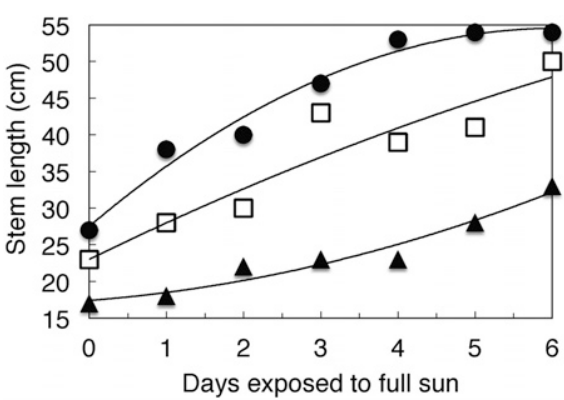

Fig. 1. Stem length of Lilium 'Tresor' plants at flowering as affected by pre-plant bulb dips (1 $\mathrm{min}$ ) into $2.5,5$, or $10 \mathrm{mg} \cdot \mathrm{L}^{-1}$ flurprimidol that had been exposed to full sunlight for 0 to $6 \mathrm{~d}$ (Expt. 1). The stem length of non-treated plants was $55.7 \pm 4.3 \mathrm{~cm}$. Circles: $2.5 \mathrm{mg} \cdot \mathrm{L}^{-1}, \mathrm{y}=$ $-0.738 \mathrm{x}^{2}+8.929 \mathrm{x}+27.52\left(r^{2}=0.977, P>\mathrm{F}\right.$ $0.0005)$. Squares: $5 \mathrm{mg} \cdot \mathrm{L}^{-1}, \mathrm{y}=-0.167 \mathrm{x}^{2}+$ $5.143 \mathrm{x}+23.02\left(r^{2}=0.882, P>\mathrm{F} 0.0139\right)$. Triangles: $10 \mathrm{mg} \cdot \mathrm{L}^{-1}, \mathrm{y}=0.274 \mathrm{x}^{2}+0.821 \mathrm{x}+$ $17.41\left(r^{2}=0.949, P>\right.$ F 0.0026).

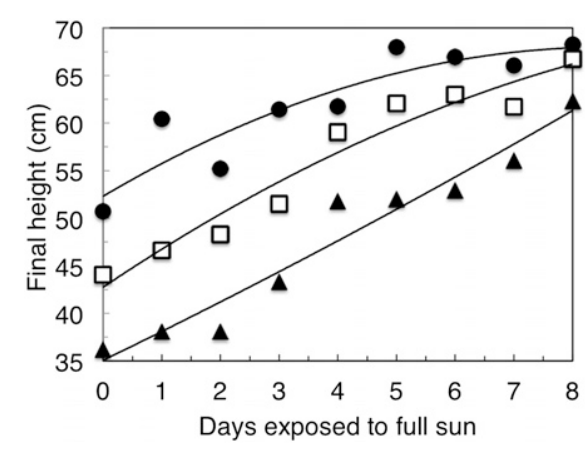

Fig. 2. Height of Lilium 'Tresor' plants at flowering as affected by pre-plant bulb dips (1 min) into $2.5,5$, or $10 \mathrm{mg} \cdot \mathrm{L}^{-1}$ flurprimidol that had been exposed to full sunlight for 0 to $8 \mathrm{~d}$ (Expt. 2). The height of non-treated plants was $68.4 \pm$ $2.9 \mathrm{~cm}$. Circles: $2.5 \mathrm{mg} \cdot \mathrm{L}^{-1}, \mathrm{y}=-0.212 \mathrm{x}^{2}+$ $3.649 \mathrm{x}+52.306\left(r^{2}=0.829, P>\mathrm{F} 0.0001\right)$. Squares: $5 \mathrm{mg} \cdot \mathrm{L}^{-1}, \mathrm{y}=-0.153 \mathrm{x}^{2}+4.155 \mathrm{x}+42.742$ $\left(r^{2}=0.946, P>\right.$ F 0.0001). Triangles: $10 \mathrm{mg} \cdot \mathrm{L}^{-1}$, $\mathrm{y}=0.036 \mathrm{x}^{2}+2.998 \mathrm{x}+35.062\left(r^{2}=0.947\right.$, $P>$ F 0.0001).

experiments conducted outdoors in the midwestern United States from June to approximately September, conditions that are comparable to those in the present experiments. The bioassay 
Table 3. Environmental conditions during the two photodegradation experiments.

\begin{tabular}{lccc}
\hline Days in sunlight & Avg temp $\left({ }^{\circ} \mathrm{C}\right)$ & Avg irradiance $\left(\mathrm{W} \cdot \mathrm{m}^{-2}\right)$ & Cumulative irradiance (MJ) \\
\hline 1 & $23.21^{\mathrm{z}}$ & $544^{\mathrm{y}}$ & $29.4^{\mathrm{x}}$ \\
2 & 25.2 & 535 & 58.3 \\
3 & 28.6 & 431 & 81.6 \\
4 & 27.8 & 419 & 104.2 \\
5 & 26.9 & 522 & 132.4 \\
6 & 29.7 & 567 & 163.1 \\
& & & \\
1 & 28.8 & \multicolumn{2}{c}{ Expt. 2} \\
2 & 24.6 & 310 & 22.1 \\
3 & 26.4 & 304 & 40.7 \\
4 & 29.3 & 400 & 57.1 \\
5 & 31.7 & 383 & 78.8 \\
6 & 30.5 & 387 & 99.4 \\
7 & 24.5 & 171 & 120.4 \\
8 & 24.0 & 445 & 129.6 \\
\hline
\end{tabular}

${ }^{\mathrm{z}}$ Average temperature, sunrise to sunset, based on 15-min readings.

'Irradiance, averaged from 15-min readings, sunrise to sunset.

${ }^{x}$ Derived from average irradiance and daylength of $15 \mathrm{~h}$.

method used in the present work does not allow determination of a half-life per se because the result is dependent on the initial PGR concentration and sensitivity of the cultivar being used for bioassay. Even so, the significant loss of activity seen over several days of sunlight exposure supports the rapid photolysis demonstrated in the earlier report (Chand and Lembi, 1994) and suggests greenhouse and nursery producers should take steps to protect flurprimidol solutions from direct sunlight if they are to be used over an extended period.

In the present work, the 4- and 7-week-old flurprimidol solutions were stored in darkness at $17^{\circ} \mathrm{C}$ before being used in the experiment, so no photolysis occurred. The results show that overall degradation in darkness must have been minimal. Assuming a half-life of $8.4 \mathrm{~d}$ (Chand and Lembi, 1994), the 4- and 7-week periods represent 3.3 and 5.8 half-lives, which theoretically would reduce the initial concentrations of $30 \mathrm{mg} \cdot \mathrm{L}^{-1}$ to 3.0 or $0.52 \mathrm{mg} \cdot \mathrm{L}^{-1}$ (assuming no microbial degradation or adsorption). Given that the minimal effective concentration of flurprimidol for hyacinth and daffodil height control as a pre-plant dip is in the $10-$ to $20-\mathrm{mg} \cdot \mathrm{L}^{-1}$ range (Krug et al., 2006a, 2006b; Miller, 2012b, 2012c), differences in height between bulbs dipped into the aged and freshly prepared solutions would have been apparent if significant degradation were occurring in darkness. Thus, flower bulb forcers can use flurprimidol solutions for at least 4 to 7 weeks if they are held in darkness. Tulip, hyacinth, and narcissus bulbs are free of adhering soil, and repeated dipping into a PGR solution yields relatively little debris in the solution. Additional work should be conducted to determine long-term efficacy of flurprimidol solutions used for dipping products that have a significant amount of adhering soil, peat, or other biological substrate (Lilium bulbs, young plants in plug trays, etc.).

\section{Conclusions}

Results from these experiments indicate that when protected from sunlight, flurprimidol solutions are rather long-lived and suggest that bulb forcers should be able to use flurprimidol dip solutions to treat spring flowering bulbs for 4 to 7 weeks in the fall planting season as long as the solutions are kept in darkness and not exposed to direct sunlight. Significant loss of growth-regulating activity was seen when flurprimidol solutions were exposed to full midsummer sunlight for as little as $1 \mathrm{~d}$.

\section{Literature Cited}

Anonymous. 2012a. Flurprimidol. Crop protection database. 17 Nov. 2012. <http://www.agropages. com/AgroData/Detail-697.htm>.

Anonymous. 2012b. Kaye and Laby online. 17 Nov. 2012. <http://www.kayelaby.npl.co.uk/ chemistry/3_4/3_4_2.html>.

Chand, T. and C.A. Lembi. 1994. Dissipation of gibberellin synthesis inhibitors in small-scale aquatic systems. J. Aquat. Plant Mgt. 32:1520.

Krug, B.A., B.E. Whipker, I. McCall, and J.M. Dole. 2006a. Narcissus response to plant growth regulators. HortTechnology 16:129-132.

Krug, B.A., B.E. Whipker, and I. McCall. 2006b. Hyacinth height control using preplant bulb soaks of flurprimidol. HortTechnology 16:370 375 .

Larson, R.A., C.B. Thorne, R.R. Milks, Y.M. Isenberg, and L.D. Brisson. 1987. Use of ancymidol bulb dips to control stem elongation of Easter lilies grown in a pine bark medium. J. Amer. Soc. Hort. Sci. 112:773777.

Lilly Research Laboratories. 1983. Technical report on EL-500. Eli Lilly and Company, Indianapolis, IN.

Miller, W.B. 2012a. Website for the Flower Bulb Research Program at Cornell University. 17 Nov. 2012. <http://www.flowerbulbs.cornell.edu/>.

Miller, W.B. 2012b. Narcissus dip summary table. 17 Nov. 2012. <http://www.flowerbulbs.cornell. edu/forcing/narcissus/narcissus_dip_summary. pdf $>$.

Miller, W.B. 2012c. Hyacinth dip summary table. 17 Nov. 2012. <http://www.flowerbulbs.cornell. edu/forcing/hyacinth/dip summary table.pdf $>$.

Miller, W.B. 2013. Production chain, forcing physiology and flower production systems, $\mathrm{p}$. 287-332. In: Kamenetsky, R. and H. Okubo, eds. Ornamental geophytes: From basic science to sustainable production. CRC Press, Boca Raton, FL.

Ranwala, N.K.D., A.P. Ranwala, and W.B. Miller. 2005. Paclobutrazol and uniconazole solutions maintain efficacy after multiple lily bulb dip events. HortTechnology 15:551-553. 